\author{
Maria Fátima PAIXÃO ${ }^{1}$ and António CACHAPUZ ${ }^{2}$ \\ ${ }^{1}$ Instituto Politécnico Castelo Branco, Escola Superior Educação \\ ${ }^{2}$ Universidade Aveiro, Departamento Didáctica Tecnologia Educativa
}

\title{
MASS CONSERVATION IN CHEMICAL REACTIONS: THE DEVELOPMENT OF AN INNOVATIVE TEACHING STRATEGY BASED ON THE HISTORY AND PHILOSOPHY OF SCIENCE
}

Received: 15 November 1999; revised: 13 December 1999; accepted: 12 January 2000

\begin{abstract}
A detailed analysis of recent Portuguese Curricular Reform materials (low secondary school, 13-15 years old students) shows that the topic of "mass conservation in chemical reactions" is a central one. However, the proposed teaching approach is a traditional one, emphasizing the learning of isolated concepts and science processes. New and different teaching approaches are necessary and these must consider the history and the philosophy of science, so that aspects related to the context of discovery are also considered. This is an important point in the light of new Science Education aims, which take into account the development of adequate images of science and scientific knowledge. The main aim of this study is to present and discuss a new teaching approach based on research carried out in the last four years. The main lines of the approach presented is epistemologically based on the New Philosophy of Science. It departs from the combustion reactions and their contemporary economical, environmental, social and political contexts (exploring STS perspectives in the teaching of science). Its exploration is centred upon the context of oxygen theory discovery and the main teaching aims are discussed. Strategies, activities and materials used are presented and their educational purposes are accounted for with reference to the theoretical framework developed. Internal evaluation based on feedback of the two teachers who developed the strategy and of the students involved converge towards the acknowledgment of the interest of the new proposal. [Chem. Educ. Res. Pract. Eur.: 2000, 1, 201-215]
\end{abstract}

KEY WORDS: chemical reactions; history of chemistry; teaching strategy; philosophy of science; experimental work; STS

\section{INTRODUCTION}

Despite some specific dissimilarities among contemporary science philosophers, particularly Kuhn, Lakatos, Toulmin or Feyerabend, a coherent image of science with important implications for science education emerged during the end of 80' and 90's (Cleminson 1990; Duschl \& Guitomer 1991; Hodson 1985, 1986, 1996; Gil-Pérez 1996; Duschl 1990; among others.):

1. Scientific knowledge cannot be equated as an absolute truth, it has temporary status and errors must be the object of reflection.

2. Scientific discoveries have a context and structure and the history of science helps us to understand those aspects. 
3. Scientists are part of the very world they investigate and they must constantly submit their results to the certification of a scientific community.

4. There does not exist a unique and singular method of producing scientific knowledge but a context-dependent methodological pluralism.

5. Observation does not exist apart from a theory that guides and gives meaning to it. Scientific theories interpret and explain the world tentatively.

6. Science is not objective, impersonal and problem-free, but it is closely related to society and technology.

The need for a strong relationship between the philosophy of science (PS) and science education is pointed out by several authors, who have stressed the importance of basing the teaching of science on established guidelines of the PS (Forge 1979; Abimbola 1983; Hodson 1986; Matthews 1989; Brickhouse 1989; Cleminson 1990; Níaz 1994; Monk \& Osborne 1997; among others). The structure of science, the nature of scientific methodology and the value intention of scientists' judgements, are some of the areas in which the PS component may represent an enrichment to science teaching. As Hodson (1986) stated:

"Implicit messages are evident in the choice of content and learning methods, particularly in the relative emphases afforded to 'knowledge' or 'process' and in the role of laboratory work."

He added: "The nature of that laboratory work may well be a crucial factor determining children's understanding of what scientists do and their attitudes towards science and scientists."

In other words, the lack of consideration of objectives which have to do with the understanding of the nature of science is due to the confusion in the philosophical perspective presented in the curriculum and also to the lack of an adequate understanding of basic aspects of the PS and of its importance in the design of teaching strategies.

Transmitting messages about the nature of science and of scientific activity has an influence on students' attitudes as far as science is concerned and it may influence the students' option for a scientific course. If we want students to acquire an adequate understanding and appreciation of this subject it is necessary for philosophical considerations to have more prominence in their science learning situations.

Most of the authors mentioned above referred to the teachers' need to understand the epistemological basis of the science curriculum in the light of contemporary views on the philosophy and sociology of science.

These contemporary philosophical views, mainly based on Kuhn's and post-Kuhnian perspectives while seeking a more externalist perspective of the building of science, may be organised in order to constitute a certain number of relevant points of view about the scientific curriculum. As Abimbola (1983) stated, the New Philosophy of Science (NPS) confer "the necessary guidance to upgrade science education research and practice". In our view, such guidance should involve at least three important aspects which are summarized in the following.

\section{Valuation of the history of science}

One of the most valuable aspects of the new perspectives of Science Education based on the NPS is the use of the History of Science (HS) as a way of presenting a human activity (Nielsen \& Thomsen 1990) in a strong cultural, social and ethical sense. Such an approach permits a more global understanding of the nature of science, scientific knowledge and the 
work of scientists which develops in special human communities. To take this into account represents a contribution to having autonomous citizens in a pluralist society, as against the apparent neutrality of science or to excessive worship of scientism (Sprod 1993). There is little interest in the presentation and interpretation of a reality as a well-established and history-free concept. Scientific knowledge is also a human and cultural product, which is contingent, and we cannot understand its nature and the sense of its fulfillment without knowledge of its historical contexts. To the question "what is the history needed?", Monk \& Osborne (1997) spoke of "a history of the creation of those ideas, the people who created them and their impacts on society". There are, in fact, many arguments defending the inclusion of HS in curriculum and especially in teaching strategies (Dana 1990; Matthews 1990; Bybee et al. 1991), but very few studies exploring this perspective in chemistry education have been published.

\section{Re-evaluation and reorganization of experimental work}

We cannot separate experimental work (EW) from science/chemistry teaching. This is why there is a long history concerning the use of EW in the science classroom (Jenkins 1989). Either the content-centered or the process-centered approaches to EW assume that scientific knowledge is perfect and complete, objective and cumulative of parts of truth about reality. For these perspectives, the emphasis is on the transmission of facts, laws and theories. In the pretentious discovery of these by direct and systematic observation of reality (discoveryapproaches), EW appears as an activity in which students are assumed to be neutral and objective observers, who, when following an established set of rules, obtain secure data for correct scientific explanations. After the 80's, a movement of re-evaluation and reorganization of EW developed (Hodson 1996), chiefly as a result of the changing views of Science Education influenced by the NPS and constructivist psychology. New aspects emphasizing the problematic and conjectural character of scientific knowledge as well as the key role of the students in the (re)construction of their knowledge are now being considered. At the methodological level the role of EW evolved from confirmatory/verification activities to experimental situations aiming to explore cognitive conflicts and co-operative learning among students. It is within this new framework, with this external epistemological point of view, that EW in the classroom now makes sense (Cachapuz et al., 1999).

\section{Consideration of STS perspectives}

Many science education researchers agree with the relevance of the STS movement in Science Education (Fensham, 1990; Vaz \& Valente, 1995; Solomon, 1994; Iglésia, 1997). There is an increasing interest in the relationships which students can perceive between science, social and technological aspects in modern societies. According to the ideas of the STS movement the study of technology may be interrelated with science and their social dependencies. Fleming (1989) proposed that technological literacy may be directed to the education of citizens with critical abilities in the face of technology. Such a person may have the capacity to inform him/herself and reflect on socially and technologically important and decisive questions.

A STS-based science curriculum may facilitate an adequate understanding about the nature of science and the development of scientific knowledge as well as to promote adequate values and ethical aspects. This represents a major aims of science education all over the world. This implies students learning in a problem-solving-centered context. These problems should be real world problems, involving a STS dimension. 


\section{THE PROBLEM}

Recent research with Portuguese Chemistry teachers suggests that they have difficulties in interpreting the epistemological dimensions of new curricular proposals (Paixão \& Cachapuz, 1998). Furthermore, a more in depth study involving a naturalistic observation of 40 hours of classroom teaching (Paixão \& Cachapuz, 1999) shows that chemistry teachers frequently use a traditional approach to teach the topic of mass conservation in chemical reactions.

The emphasis is on the learning of isolated concepts and science processes. The topic is usually approached exclusively as academic content for the solving of exercises dealing with the balancing of chemical equations and stoichiometric problems. The fact is that even when students are able to solve the problems, this does not necessarily correspond to an understanding of the issues. When some practical work is developed in classrooms, it is far from the defended epistemological principles. Frequently proposed work in the theme is a confirmatory epistemological perspective involving, generally, the 'classical' chemical reaction of precipitation of the lead iodide by reaction between potassium iodide and lead nitrate. Thus, almost a decade after a major reform in Portuguese education we still are confronted with chemistry practices which do not take in consideration new perspectives of science education referred to above.

The aim of this study is to present and discuss a new teaching strategy of "mass conservation in chemical reactions" that was implemented by two chemistry teachers after their participation in a teacher education programme (TEP) which provided them with an epistemological base for understanding the educational relevance of the NPS aspects referred to above in their classroom practices. This programme involves a reconsideration of the role of the History of Science, a re-organization and re-orientation of the experimental work and the need to take in consideration the STS perspective.

An interrelated set of reasons converged to the selection of the theme of mass conservation in chemical reactions. Firstly, it is a central theme in the programme of low secondary school (14/15 years old pupils). Secondly, it is a prerequisite for the subsequent understanding of chemistry. From a scientific point of view, the understanding of the mass conservation principle, as well as the knowledge of the general theory of chemical reactions, is indispensable for the whole understanding of Chemistry in subsequent studies.

From an epistemological point of view the study of the controversy which surrounded the interpretation of the combustion common reactions and the establishment of a general theory of chemical reactions, based on the principle of mass conservation that guided Lavoisier in the establishment of his theory of oxygen, cannot be underestimated. We cannot ignore these questions in the process of scientific knowledge building, frequently passed on to students as an empirical way of doing science (Praia \& Cachapuz, 1998).

The theme is also important in social, technological, political and environmental contexts, especially when one thinks about combustion reactions and the concept of mass conservation, e.g. thermoelectric power stations, incinerating, recycling.

There exists a lot of research that points out the existence of students' misconceptions concerning this theme (Hesse \& Anderson, 1992; Yarroch, 1985; Ben-Zvi et al., 1987).

It is also an important historic and cultural theme because it corresponds to a strong period in the history of mankind (the French Revolution) with many economical, social and political implications. After the commemoration of 200 years since Lavoisier's death, the quantity and quality of available literature has increased (Bensaude-Vincent \& Stengers 1996). This literature can give a context to the building of scientific knowledge allowing a more interesting non-neutral view of science. 


\section{THE STUDY DESIGN}

Although the two teachers involved in the study (called, shortly, A and C) were chosen from among a set of enthusiastic teachers who had volunteered to participate in the research, we did not expect the two teachers to be able to develop chemistry teaching in the light of new perspectives. This is why a complete Teacher Education Programme (TEP) was conceived to help teachers to gain first an adequate understanding of the nature of science, of the social construction of science and scientific knowledge and of the necessarily associated technological development (critical STS perspectives) (Matthews 1994) and the indispensability of including the History of Science in chemistry teaching within an epistemologically based approach. Thus, the actual study was integrated in a larger study (Paixão \& Cachapuz,1998; Paixão, 1999) using a longitudinal design with three main phases. In the first, 40 hours of chemistry teaching of four chemistry teachers (including the two teachers of the present study) was video-recorded and written protocols produced: these were subjected to a content analysis, using a previously developed theoretical instrument congruent with the guiding principles of the new philosophy of science (Figure 1). This was done in order to help us to characterize the nature of the main difficulties experienced by the teachers involved.

The second phase involved the development of an alternative strategy to teach mass conservation in chemical reactions (co-operative planning work, involving the two chemistry teachers and researchers). This also involved the design of the new teaching materials. In the third phase, the new teaching strategy was implemented by the two teachers in their classes, involving 50 students (again written protocols corresponding to 16 hours of teaching were prepared and analysed).

The present report focuses on the last phase. We involved teachers in a co-operative action research study in order to conceive and explore innovative chemistry teaching strategies exploring the HPS (Monk \& Osborne 1997). We analysed and discussed the way they can implement them in the classroom.

We planned a set of one-hour classroom units in order to implement them as a whole classroom strategy based on the HPS according to the principles referred to above (Figure 2). General goals, activities (particularly some aspects of EW) and materials used are presented and their educational purposes are accounted for with reference to the theoretical framework developed.

There follows the proposed and developed strategy we designed in collaboration with the involved teachers in order to demonstrate the epistemological approach on the programmatic central theme: Mass conservation in chemical reactions.

\section{THE DEVELOPMENT OF THE TEACHING STRATEGIES}

The teaching strategy considered as indispensable prerequisites the concepts of mass, symbolic representation and the operative concept of chemical transformation. Guided by the idea of the importance of an STS context in science education, we started (see Figure 2) with the presentation and discussion of a set of situations where combustion plays a central role: the discovery of fire and its domestic applications, wood fires, recycling, industrial situations, thermoelectric power stations... Combustion was identified as a chemical reaction and some central aspects which implies gathering students' opinions were discussed.

The problematic question that guided the development of the teaching strategy was whether mass (determined with by weighing scales) is conserved or not when a material burns 


\begin{tabular}{|c|c|c|}
\hline $\begin{array}{l}\text { Epistemological } \\
\text { Categories }\end{array}$ & Analysis Dimensions & $\begin{array}{c}\text { Teaching Practice Indicators } \\
\text { (examples) }\end{array}$ \\
\hline \multirow[t]{2}{*}{$\begin{array}{l}\text { I - Scientific } \\
\text { Methodology }\end{array}$} & $\begin{array}{l}\text { A - Methodological } \\
\text { pluralism }\end{array}$ & $\begin{array}{l}\text { Explicit references to some episodes of the HS and/or current } \\
\text { aspects of scientific investigation with relevance to different } \\
\text { scientists' working methods. } \\
\text { Discussion of students' ways of working with clarification of } \\
\text { the means of selecting experimental proceedings and their } \\
\text { adequacy and/or limitation (not recipes). }\end{array}$ \\
\hline & $\begin{array}{l}\text { B - Theory / } \\
\text { Observation / } \\
\text { Experiment relations }\end{array}$ & $\begin{array}{l}\text { Theoretical considerations before observation and } \\
\text { experiments. } \\
\text { Initial problematic questions and predictions. } \\
\text { Critical report of the Experimental Work orientated by } \\
\text { problematic questions and including critical assessment of the } \\
\text { results }\end{array}$ \\
\hline \multirow{2}{*}{$\begin{array}{l}\text { II - The dynamics } \\
\text { of Scientific } \\
\text { knowledge } \\
\text { construction }\end{array}$} & $\begin{array}{l}\mathrm{C}-\text { Scientific } \\
\text { discovery } \\
\text { Context and structure }\end{array}$ & $\begin{array}{l}\text { Activities exploring historical controversies in the } \\
\text { establishment of a respected scientific theory } \\
\text { (i.e. texts and related questions) }\end{array}$ \\
\hline & $\begin{array}{l}\text { D - Error /Truth } \\
\text { Dynamics }\end{array}$ & $\begin{array}{l}\text { Intentional valuation and exploration of students' errors. } \\
\text { Identification of misconceptions. } \\
\text { Discussion of discrepant Experimental Work results. }\end{array}$ \\
\hline \multirow[t]{2}{*}{$\begin{array}{l}\text { III - The human } \\
\text { and social side of } \\
\text { science }\end{array}$} & $\begin{array}{l}\text { E - Images of } \\
\text { scientists and the } \\
\text { scientific community }\end{array}$ & $\begin{array}{l}\text { Explicit references to the human side of scientists. } \\
\text { Opportunities for the students to express their own ideas and } \\
\text { confront them with their colleagues' ideas and/or with the } \\
\text { current scientific version. }\end{array}$ \\
\hline & F - STS interrelations & $\begin{array}{l}\text { To begin with a social or a technological problem. } \\
\text { To promote intentional discussions (debate) about science } \\
\text { related questions, showing the relation between science and } \\
\text { technology, and ethical or environmental questions... with the } \\
\text { opportunity for students to express their established ideas. }\end{array}$ \\
\hline
\end{tabular}

FIGURE 1. Instrument of teaching practices analysis.

(combustion). Students noted down their initial ideas for confronting them later (they wrote the date and the context in which these ideas appeared).

The teacher discussed with the students the meaning of "theory". The concept might already be familiar (from the particulate theory). A text referring to the first great chemical theory was discussed in small workgroups. Some students might reinforce their ideas about mass changing in combustion reactions.

After this step, the question about mass conservation or non-conservation in chemical reactions makes sense: The following situations, that is, the open system combustion of alcohol, iron, and cotton (domestic materials), were proposed to the students and intended to create cognitive conflict situations. Two solid materials were then proposed (iron and cotton) which lead to different conclusions (in the case of iron the mass seemingly increases whereas in the case of cotton it decreases); also, a liquid material was proposed (alcohol) which has a similar behaviour to that of cotton. The aim was to give the students the opportunity to make predictions with the support of a defended theory. The interpretation of the results by most of the students was done in the light of the defended theory, the Stahl's phlogiston theory. It may be that the students do not defend the same theory and that they have different expectations. Now is the time for the teacher to make a parallel between the history of chemistry and the way the ideas developed in the class. This was the opportunity to make some reference to the "pneumatic chemistry" development with reference to the work of 


\begin{tabular}{|c|c|c|}
\hline Lesson & Aims & Strategy/Material \\
\hline $1 / 2$ & $\begin{array}{l}\text {-To understand that a scientific theory needs to be } \\
\text { explicative } \\
\text {-To make predictions based on an acceptable } \\
\text { theory } \\
\text {-To identify the difficulties in the theory of } \\
\text { phlogiston for explaining the reactions in } \\
\text { combustion } \\
\text {-To acknowledge the need for a theory to guide } \\
\text { the experiment }\end{array}$ & $\begin{array}{l}\text { - Contextualization (slides)/problem -question: "Does } \\
\text { mass conserves when a material burns"? } \\
\text { - Registering of students' ideas } \\
\text { - Reading of and response to the questions in the text: } \\
\text { "A theory for interpreting the chemical reactions of } \\
\text { combustion" } \\
\text {-Experimental demonstration preceded by predictions } \\
\text { based on acceptable theories } \\
\text {-Registration of Experimental Work (EW1) } \\
\text { - Confronting experimental results with the ideas from } \\
\text { Text } 1 . \\
\text { - Reading of the text: "On the way to a theory for } \\
\text { interpreting the reactions of combustion". }\end{array}$ \\
\hline $3 / 4$ & $\begin{array}{l}\text { - To promote interaction between different } \\
\text { academic subjects Chemistry- History } \\
\text { - To extend knowledge about History of } \\
\text { Chemistry } \\
\text { - To reflect on the importance of the social, } \\
\text { cultural and technological context }\end{array}$ & $\begin{array}{l}\text { - Execution of the worksheet EW2: "The composition } \\
\text { of the air" } \\
\text { - Registration of the EW2 } \\
\text { - Discussion of the answers to the questions on the } \\
\text { worksheet EW2 and in Text } 2 \text {. } \\
\text { - Reading of text } 3: \text { :A new theory for interpreting the } \\
\text { reactions of combustion". }\end{array}$ \\
\hline $4 / 5$ & $\begin{array}{l}\text { - To understand the process of replacing one } \\
\text { theory with another. } \\
\text { - To organise the conceptual outline of the theory } \\
\text { of oxygen } \\
\text { - To assess the power of prediction of a theory. } \\
\text { - To reflect on the role of the scientific } \\
\text { community } \\
\text { - To assess the importance of the social, cultural } \\
\text { and technological context in the development of } \\
\text { scientific knowledge. }\end{array}$ & $\begin{array}{l}\text { - Analysis of the answers to the questions in text } 4 \text { (read } \\
\text { by the students or used by the teacher): "Lavoisier } \\
\text { achieves the synthesis of water - The low of mass } \\
\text { conservation in chemical reactions" } \\
\text { - Summing up of the situation, accompanied by the } \\
\text { projection of transparencies: presentation of the } \\
\text { principle of mass conservation, illustrations of } \\
\text { Lavoisier's experimental outlines... } \\
\text { - Beginning of experimental planning on the worksheet } \\
\text { EW3 and on the analysed texts. }\end{array}$ \\
\hline $\begin{array}{l}\text { (Home } \\
\text { work) }\end{array}$ & $\begin{array}{l}\text { - To plan experiments and to register } \\
\text { observations } \\
\text { - To interpret experiments in the light of an } \\
\text { acceptable theory } \\
\text { - To understand the scientist as a person in his } \\
\text { own time } \\
\text { - To understand the dynamic and controversial } \\
\text { building of science } \\
\text { - To understand that science evolves in a social, } \\
\text { cultural context. }\end{array}$ & $\begin{array}{l}\text { - Continuation of the planning of experiments to } \\
\text { confront the hypothesis that oxygen is necessary for } \\
\text { combustion and the mass remains (students' projects). } \\
\text { - Elaboration of a list of materials, on outline and } \\
\text { procedures. } \\
\text {-Presenting the teacher with experimental proposals. } \\
\text { Execution of the experiments conceived by the } \\
\text { students. Registration of results. } \\
\text { - Reading of the text5: "The way a scientific theory is } \\
\text { changing and Lavoisier's time" }\end{array}$ \\
\hline $6 / 7$ & $\begin{array}{l}\text { - To understand the power of prediction of a } \\
\text { scientific theory } \\
\text { - To understand the law of mass conservation in } \\
\text { chemical reactions }\end{array}$ & $\begin{array}{l}\text { - Second problem-question: "Does mass conservation } \\
\text { occur in chemical reactions, other than in } \\
\text { combustion's?" } \\
\text { - Execution of the set of different experiments by } \\
\text { different groups of students (EW 4). } \\
\end{array}$ \\
\hline $7 / 8$ & $\begin{array}{l}\text { - To communicate results } \\
\text { - To understand the role of scientific communities } \\
\text { in certifying scientific knowledge. } \\
\text { - To modify representations about science. }\end{array}$ & $\begin{array}{l}\text { - Preparation of material for presenting the results to } \\
\text { classmates } \\
\text {-Communication of the results to the class (students' } \\
\text { materials) }\end{array}$ \\
\hline \multirow[t]{2}{*}{$8 / 9$} & $\begin{array}{l}\text { - To represent chemical reactions in the form of } \\
\text { chemical equations }\end{array}$ & $\begin{array}{l}\text {-Oral explanation of the meaning of symbolic writing in } \\
\text { the form of chemical equations by means of outlines in } \\
\text { words of the reactions executed. }\end{array}$ \\
\hline & - To discuss the interrelationship STS & - School trip to a thermal power station \\
\hline
\end{tabular}

FIGURE 2. Teaching plan. 
Priestley, Black and Cavendish on the identification of gases. Consequently, students may begin to suspect that something does, in fact, interfere in combustion.

We prepared appropriated versions of texts about Lavoisier's ideas and descriptions of particular experiments he did with many of his collaborators. These texts were translated and adapted by the authors from the original French books of XIX century (Lavoisier 1864) (Figure 2/ Lessons 2,3,4). There are three main stages in the evolution of Lavoisier's ideas about combustion: First, he suspected that something in the air interferes in combustion and he does a set of combustion reactions, namely using lead and phosphorous. After reading and discussing such a text, students may do the usual experiment of combustion of a candle or a piece of cotton under a campanile on the water. The second stage was the identification of oxygen gas participation in combustion reactions. He explained the combustion reactions taking into account Priestley's contributions. Although this important work in the obtainment of the gas oxygen, he keeps his engagement with the phlogiston theory. The third stage of Lavoisier's ideas was the public demonstration of his interpretation of mass conservation in combustion and the public confrontation with his "phlogiston" adversaries, namely the prestigious English chemist Priestley. Making the water synthesis with the collaboration of Meusnier, he discredited the ancient phlogiston theory and explored the oxygen theory.

Now students were in a position to give tentative answers to the initial question. Their question now is how to resolve the problem of mass control in initial experimental proposed situations? The students had the opportunity to make decisions, design experimental situations, control experiments and prepare the results to communicate them to their colleagues (Fig 2/ Lessons 4,5).

Finally, a text with some central aspects of Lavoisier's biography associated with the whole context in which he lived was also prepared and discussed with the students. This text made possible to highlight the human dimension of science through its protagonists.

In the last step, students have the opportunity to extend their understanding of mass conservation in chemical reactions. The teacher can ask the question: Does mass conservation occur in other chemical reactions, besides combustion? And they can try some other experiments (Figure 2/Lessons 6,7). There are different kinds of chemical reactions, namely copper sulphate with calcium hydroxide, hydrogen chloride (acid) with calcium carbonate, chloride acid with magnesium, nitric acid with copper or the reaction between potassium iodide and lead nitrate. They may write the chemical equation in words and after this systematic study the chemical equation balancing can easily be done (Figure 2/Lessons 8,9). Discussions of the results obtained by different groups of students should follow.

\section{Relationship between the developed teaching strategy and the guiding principles of NPS}

Following the presentation of the main steps in the development of the teaching strategy by the teachers involved in the study, we now present some details of the dialogues between each teacher and their students taken directly from the video-recorded protocols that illustrate aspects of the proximity between the developed teaching strategy and the guiding principles of NPS specified in the instrument of teaching practices analysis (Figure 1) by the categories defined by the dimensions of analysis and exemplified by the indicators of teaching practice.

\section{I - Scientific methodology \\ A- Methodological pluralism}

Clearly shown is the way Lavoisier developed his investigation, how he carried out his 
experiments and the demand for methodological rigour:

$\mathrm{T}$ - (...) And so Lavoisier started to study this matter, right? In keeping with other different hypotheses... What I have here for today is a very good text which is... Did you know that Lavoisier was a very diligent, very meticulous scientist... Or, in other words, whenever he had to do an experiment he noted down everything, absolutely everything about the experiment, everything he did, everything that happened, he describes his conclusions $(5: 00)$ he described the set ups that imagined... (...) I have a photocopy of... of the work... of his book... of the notes in his laboratory notebook. I told you, do you remember? At the beginning of the year. I told you that you should have a laboratory notebook... Scientists always have a laboratory notebook where they note down everything... and where they have their drawings (showing the drawings of the set ups used by Lavoisier). (Teacher(T) A)

\section{B - Theory/observation/experiment relations}

After the contextualized introduction, the importance of studying combustions as particularly important chemical reactions and the need for scientific theories to interpret the phenomena becomes obvious. Even in the demonstration modality the teacher makes it clear that a theory is known, that this is the starting point for the experiment and the predictions are made on that basis:

T- In the last lesson we carried out three experiments... and that was because we are looking for the answer to a question which is... (teacher and students in chorus; the teacher writes the initial question on the board again) Now then, this is our basic question and like the scientists, we are looking for the answer to it. We started by reading a text which gave us the theory of a great seventeenth century scientist called Stahl. (1:00). To sum up and conclude, did Stahl think that there was mass conservation in chemical reactions or not? What did Stahl think?

S- That there wasn't!

T- (...) We did the combustion of alcohol, we did the combustion of cotton, we did the combustion of steel wool and what conclusion did we come to?... concerning the... the combustions?

S- The cotton decreased.

T- The mass (emphasising the word) of the cotton... decreased. Due to combustion. And what about the mass of the alcohol?

S- It decreased.

T- It also decreased (the students complete the results with the teacher; they consult the notes in their exercise books). (3:00) And what about the mass of the iron in the steel wood?

$\mathrm{S}$ (several students)- It increased.

T- It increased... slightly, but it did increase. That is what we saw. Now then, if Stahl... Sorry, go ahead!...

S- He only worked with metals!

T- Only with metals... May be that... there... let's say... was his mistake, right?

$\mathrm{S}$ - Because combustion doesn't only exist with metals...(T A)

\section{II- The dynamics of scientific knowledge construction C- Scientific discovery context and structure}

The sequence taken is made explicit in History of Science terms, which led to the solution of the theory of oxygen. The teachers illustrate with various materials, including a copy of Lavoisier's written records, descriptions of the units of mass used at that time and referred to in Lavoisier' s descriptions, drawings by his wife, Anne Marie Paulze, etc.

T- But did part of the air stay in the recipient? (...) (the students discuss) Then for what 
reason did the water rise in the recipient? How did you answer? $(7: 00)(\ldots)$

T- What was the approximate volume of the air which participated in the reaction?... Lavoisier thought it was a fifth... according to his similar experiments, in the text we read here... Now, which gas participates in the combustion reaction?

S- Oxygen.

T- Oxygen. We already knew that, didn't we? Think about the composition of air. It doesn't only contain oxygen....

S- Oxygen, nitrogen, water.

$\mathrm{T}$ - Traces of carbon dioxide... it's a mixture of gases, isn't it?

S- Homogeneously...

T- Now, another question: (10:00) "When Lavoisier carried out his experiment, which was very similar to the one you carried out, would he have been convinced immediately that oxygen from the air participated in combustions?" (among the students, some say yes but must say no)

T- He said no. Why?

$\mathrm{S}-\mathrm{He}$ didn't know what oxygen was.

T- That's right (goes to write on the board). Because he didn't know what the components of air were... Did anyone else answer this question? (T A)

\section{D - Error/Truth dynamics}

The teacher points out that "mistakes" are normal part of scientific experience:

S- Oh, teacher... (they try to interrupt) A clue. This is a clue (the students consult their notebooks).

T- Listen, listen to what your classmate said. We... Did Lavoisier always carry out his experiments in enclosed spaces?

$\mathrm{S}-\mathrm{Yes}$, in enclosed spaces.

T- In enclosed spaces. How did we do the experiments?

S- In an open space.

S- That's what I was thinking...

T- Why didn't you say so? You're all too afraid to say what you think. You should have said!

You've seen great chemists make mistakes! Today... (43:00) Today they are considered jokes... Now, let's see: why do you think that what your classmate is saying is important?

$\mathrm{S}$ - If the mass decreased it's because it was in an open space...

$\mathrm{T}$ - Then why did it decrease in an open space?

S- Gaseous...

T- What was in a gaseous state? The alcohol wasn't gaseous.

S- So it was no longer alcohol (44:00).(T C)

\section{III- The human and social side of science}

\section{E - Images of scientists and scientific community}

One of the important aspects, from an epistemological point of view, has to do with the allusion which is made to the social value of scientific knowledge, and the need for public acknowledgement, and in particular by the scientific community:

And this question is... let's say it's a question which should alert us... about how the scientists community should function... (reads the question) What was the aim?

S- For them to be present during the experiment.

T- But why? Of course to show what he did, but more important than that to show......

S- That it was true.

T- That it was true... a... scientific knowledge... something new... is only credible (10:00) if the whole scientific community believes in it too... and to accept... 
S- They are witnesses.

T- They witness and believe, right? Somebody can make a fantastic discovery but if he discovers it in his own laboratory and doesn't communicate it to the scientific community... well... they say... that first...

S- They could... (...)

S- Even that! And other people say it first! (T C)

\section{F - STS interrelations}

To give a context and importance to the study on the theme, various aspects are treated like, for example, the importance and the diversity of combustibles, in matters of economy, health, technology, environment, positive and negative effects of combustions. In this introduction to the subject, although the teacher has the most active role, the students also give some contributions:

T- A probe, right. So we want to put an object into the space and we need a rocket and for such long distances... we need... a great amount of?...

$\mathrm{S}$ - Energy...

T- Of energy, right... and we get that from a combustion, and you probably cannot even imagine which combustible we use! A gas one... hydrogen... This combustible is very frequently used in rockets (12:00). But no doubt the greatest revolution ever in terms of energy was the discovery of petroleum and its by-products. Who can tell me how we get byproducts from petroleum?

S- Distillation.

T- Say it! (insisting that the student should repeat) Distillation, plus something else! Because we get a lot from it, don't we? How did you say it? What kind of distillation?

S- Fractionated.

T- Fractionated distillation. We get so much from petroleum!... Fractionated distillation $(12: 30)(\ldots)$

T- Does combustion only bring benefits to Man, (14:30) or does it also bring serious problems?

S- Problems.

T- It brings serious problems? Can anyone tell me what kind of problems before I show you the transparency?

S- Fires.

T- Fires. Fire. And we could also talk about the pollution of the atmosphere... I haven't talked about that yet but I can hear something. What are you saying? I thought I heard...

$\mathrm{T}$ - Acid rain.

T- Acid rain. Right, someone has already told you about that. You are aware of this problem. Right, so (15:00) you can see a fire in a forest... and you can already see the gases escaping into the atmosphere which they are many times soluble in water and so produce acid rain. Later we're going to talk about that. And this photograph is a recent one. It was taken in Singapore during that big fire that you all heard so much about on T.V., I think... For months on end, in that part of the planet, a big fire... Did you hear that people even had to walk in the streets wearing?...

S- Masks. (T C)

Regarding Lavoisier's work, particular emphasis is given to the perspective of interrelated development which is interdepent on science and technology:

T- A study of water was carried out... and it says here that... two substances in the gaseous state, by combustion, will bring about a substance in the liquid state, that' s spectacular. And now, as we have already discussed question number two more or less, what technical problems had to be solved?... (to a student) What technical problems had to be solved? 
S- Material... and technical problems.

T- Material... and technical problems?... (waits) Can anyone tell him? Tell him...

S- It's the problem of nitrogen that he had to solve...

T- It's the nitrogen. You had already mentioned that... That he couldn't... that it was going to disturb (8:00) the experiment... The need to solve the way the flame is produced, the tube (a student mentions other aspects) lots of aspects...

T- Which means it is necessary to foresee that this spontaneous extinction at the moment when the emission of hydrogen gas his stronger... (reads from the text) What happened was that he had to regulate the pressure in the tubes... If the gas came out... if it came out... in combustion... it wouldn't be possible to measure the mass... (T C)

\section{CONCLUSIONS}

The main conclusion of this study is that it is possible to devise and develop a strategy of teaching "mass conservation in chemical reactions" that allows students to acquire a more effective understanding of the nature of science and scientific knowledge and its STS related development, after the teachers participation in a TEP when they are involved in a cooperative planning related to a concrete epistemological relevant theme.

We interviewed a random group of students who participated in the designed strategy and their opinions were strongly favourable to the new approach. As one of the students said:

It was a very different way of learning... It was not just arriving in the classroom and saying what the subject was.

Another student added:

We also talked about these aspects outside the school, during breaks or after the chemistry class and... in fact... we talked and... we discussed those problems.

Students recognised the main aspects involved in the strategy, like some aspects of the nature of science and scientific knowledge. About concrete aspects related to the understanding of the difficulty in changing a scientific theory one student explained: It was difficult... and it took a long time for it to be accepted. Another one spoke about Lavoisier's suspects:

... some suspects that existed a substance in the air... that he wasn't sure yet what it was... but when combined... when participating in a combustion it would allowed that the substances were burn... and without this substance the combustion wouldn't occur.

They also value work together in small groups discussing and comparing their opinions about text questions. They were able to make some predictions with the support of a theory and they could plan and conduct some simple experiments. They went beyond the simple image of science as a list of contents to memorise and they attained the understanding of the human context of science building and the part played by theory, observation and experiment.

On the teachers' side the opinions were also favourable. In particular, the two teachers understood the importance of the role of the HPS when planning and teaching science and the narrow relation between PS and science teaching. As one of them said: 
I think that is very important to situate a scientific content... in it history... in the history of science... (...) They (the students) have the idea that things drop out of the blue... About experimental work I think it is really a very important aspect... The experimental work was faced in a different perspective... Started by predictions... to attempt interpreting their hypothesis. (T A)

About the importance of the questions related to the ideas about the nature of science and its construction the teacher refers to her understanding of the importance of the training and the change it brought about in her:

Until now... I hadn't really thought about this aspect, or in other words, I didn't think it was really important how science evolved or the work that is necessary to form concepts that the teacher gives to them... that's all. (T A)

The other teacher explain her epistemological conceptions change: about the experimental method... we said that sequence of... of phases and now I start to raise objections to that sequence. (T C)

They were enthusiastic learners during the whole TEP. As the teacher A said:

The documents were interesting, it was a very good proposal... but what I considered the best during the training was effectively the dialogue between us... I felt the necessity to say and to do more in the classroom... and... it was interesting. The other teacher (C) added: I'm going... to make my teaching practice different... (...) I'm going... to improve, no doubt.

Regarding the interest of the students, and in particular as for as the presented texts are concerned, teacher A explains that: They read, understood and followed attentively. She felt that the students had no difficulty: No, no! None at all!. And explains further:

There was that phlogiston's text which was, in fact, a difficult text. I was a little afraid that they might not understand it. I was amazed! Because, in fact, they did understand it and discussed it and even helped each other at a group level. Those who knew explained to those who didn't.

The teacher A considers that the students modified the ideas they had about science and were able to construct more adequate images of science and the building of scientific knowledge. At least they now have an idea of how science was built...

The teacher $\mathrm{C}$ paid more attention to aspects which have to do with the students themselves: And therefore it was very important for me to realize how very careful we need to be, because what is obvious for us, can often be an enormous obstacle for the student.

Reflecting on the student's learning process, this teacher considers that the proposal takes on importance in the sense of learning concepts and images of science:

As for the students, it is also important because it makes them notice many facts which they would probably never have given importance to, how to give added value to personal work, viewing science not as a series of tricks or magic... but more as a result of a lot of effort... ah... a lot of effort, lengthy effort, many hours of work... a lot of dedication... the cultural side is also important, they also received... historical facts, social facts, political facts... this 
aspect was well accepted... the very politics associated with the development of science...

The teacher $\mathrm{C}$ considers that the students realized how difficult it is to change a scientific theory in the course of building scientific knowledge:

I think they realized this. You can see this in the presentation of their final texts, where they say that Priestley himself discovered oxygen or helped to do the work, and always defended the phlogiston, the phlogiston... They realize that.

The interest of the students in the classes is also referred to: I found them rather interested it was actually quite a... a surprise for me... I managed to maintain their interest in texts which they find difficult (...)I was surprised by that aspect...

Without making generalizations we can now say that we are in forefront of an interesting complete strategy for the central theme "mass conservation in chemical reactions", where various ingredients are mixed together, HS, STS relations, EW, in the midst of a contemporary epistemological atmosphere and when teachers are involved in a collaborative planning work with researchers, their teaching practices improve in a desirable way.

Our intention is to refine the actual methodology continue identifying interesting themes with particular relevant epistemological interest, developing strategies in the defended perspective and adequate teaching materials in collaboration with enthusiastic teachers.

ACKNOWLEDGEMENTS: Fundação para a Ciência e Tecnologia /PRAXIS XXI

ADDRESS FOR CORRESPONDENCE: António CACHAPUZ, Departamento Didáctica Tecnologia Educativa, Universidade Aveiro, 3810 AVEIRO,Portugal.e-mail: cachapuz@ddte.uv.pt

\section{REFERENCES}

Abimbola, I.O. (1983). The relevance of the "new" philosophy of science for the science curriculum, School Science and Mathematics, 83, 181-192.

Ben-Zvi, R.; Eylon, B. \& Silberstein, J. (1987). Students' visualisation of a chemical reaction. Education in Chemistry, 24, 117-120.

Bensaude-Vincent, B. \& Stengers; I. (1996). História da Química. Lisboa: Instituto Piaget.

Brickhouse, N.W. (1989). The Teaching of the philosophy of science in secondary classrooms: case studies of teachers' personal theories. International Journal of Science Education, 11, 437-449.

Bybee, R.W.; Powell, J.C.; Ellis, J.D.; Giese, J.R.; Parisi, L. \& Singleton, L. (1991). Integrating the History and Nature of Science and Technology in Science and Social Studies Curriculum. Science Education, 75, 143-155.

Cachapuz, A; Praia, J.; Paixão, M.F. \& Martins, I. (1999). Uma visão sobre o ensino das ciências pós-mudança conceptual: Contributos para a formação de professores. Revista de Inovação (in press)

Cleminson, A. (1990). Establishing an epistemological base for science teaching in the light of contemporary notions of the nature of science and of how children learn science. Journal of Research in Science Teaching, 27, 429-445.

Dana, T.M. (1990). The history and philosophy of science: what does it mean for science classrooms? The Australian Science Teachers Journal, 36, 21-26.

Duschl, R.A. \& Guitomer, D.H. (1991). Epistemological perspectives on conceptual change: implications for educational practice. Journal of Research in Science Teaching, 28, 839-858.

Duschl, R.A. (1990). Restructuring science education. the importance of theory and their development. New York: Teachers College Press. 
Fensham, P.J. (1990). What will science education do about technology? The Australian Science Teachers Journal, 36, 8-21.

Fleming R. (1989). Literacy for technological age. Science Education, 73, 391-404.

Forge J.C. (1979) A role for philosophy of science in the teaching of science. Journal of Philosophy of Education, 13, 109-118.

Gil-Pérez, D. (1996). New trends in science education. International Journal of Science Education, 18, 889-901.

Hesse, III, J.J.; Anderson, C.W. (1992). Students' conceptions of chemical change. Journal of Research in Science Teaching, 29, 277-299.

Hodson, D. (1986). Philosophy of science and science education. Journal of Philosophy of Education, 20, 215-225.

Hodson, D. (1985). Philosophy of science, science and science education. Studies in Science Education, 12, 25-57.

Hodson, D. (1996). Practical work in school science: exploring some directions for change. International Journal of Science Education, 18, 755-760.

Iglésia, P.M. (1997). Una revisión del movimiento educativo ciencia-tecnología-sociedad. Enseñanza de las Ciencias, 15, 51-57.

Jenkins, E.W (1989). Scientific literacy and school science education. School Science Review, 71, 43-51.

Lavoisier, A.L. (1864). Ouvres de Lavoisier. Paris: Imprimerie Impériale

Matthews, M.R. (1990). History, philosophy and science teaching. What can be done in an undergraduate course? Studies in Philosophy and Education, 10, 93-97.

Matthews, M.R. (1989). A role for history and philosophy in science teaching. Interchange, 20(2), 3-15.

Monk, M. \& Osborne, J. (1997). Placing the history and philosophy of science on the curriculum: a model for the development of pedagogy. Science Education, 81, 405-423.

Níaz, M. (1994). Más allá del positivismo: una interpretación lakatosiana de la enseñanza de las ciencias. Enseñanza de las Ciencias, 12, 97-100.

Nielsen, H. \& Thomsen, P.V. (1990). The incorporation of history and philosophy of science in physics education in Denmark. The Australian Science Teachers Journal, 36, 27-33.

Paixão, M.F. (1999). Da construção do conhecimento didáctico na formação de professores de ciências. Conservação da massa nas reacções químicas: estudo de índole epistemológica. Dissertação de Doutoramento (não publicada). Universidade de Aveiro.

Paixão, M.F. \& Cachapuz, A.F. (1998). Dimensión epistemológica de los programas de física e química e implicaciones en las prácticas de enseñanza: qué lectura hacem los profesores? In Banet, E. \& Pro, A. (Coords) Investigación e innovación en la Enseñanza de las Ciencias. Volumen I, 284293.

Paixão, M.F. \& Cachapuz, A. (1999). Challenges in Science Teacher Education for the new century: an approach based on the epistemology of curricular themes. Paper presented in the 24th ATEE. Leipzig. Germany.

Solomon, J. (1994). The rise and fall of constructivism. Studies in Science Education, 23, 119.

Sprod, T. (1993). History in science education: why, what and how. The Australian Science Teachers Journal, 39, 14-20.

Vaz, M.E. \& Valente, M.O. (1995). Atmosfera CTS nos currículos e manuais. Noesis Abril/Junho, 22-27.

Yarroch, W.L. (1985). Student understanding of chemichal equation balancing. Journal of Research in Science Teaching, 22, 449-459. 
